\title{
O PROBlema DA PROPRIEDADE PRIVAdA PARA O JOVEM MARX
}

\author{
Julia Lemos Vieira ${ }^{1}$
}

Resumo: O problema da perversão da comunidade social pela propriedade privada se tornara, para Marx, com o estudo dos socialistas utópicos e especialmente de Proudhon, bastante claro: não sendo um desenvolvimento necessário, e sim casual, a propriedade privada - e a cisão entre interesse particular e interesse geral dela proveniente - poderia ser subsumida. O presente artigo visa a demonstrar como, na busca de um republicanismo de tom rousseauniano e crítico ao liberalismo burguês, Karl Marx flertou com a crítica dos comunistas à propriedade privada. Para tanto, perpassa cinco artigos redigidos para a Gazeta Renana - o artigo de defesa contra o kantiano Hermes, a polêmica com o socialista Moses Hess, a resposta à Gazeta de Augsburg, o artigo de crítica às resoluçóes da VI Assembleia da Província do Reno e o artigo "Sobre a lei do roubo de lenha" - e, ainda, a crítica de Proudhon à propriedade privada.

Palavras-Chave: Marx. Proudhon. Estado. Propriedade privada. Democracia.

É no pano de fundo de uma tentativa de uma república não exatamente liberal, de um republicanismo de tom rousseauniano e crítico ao liberalismo burguês, que Marx começou a flertar cada vez mais com a crítica dos comunistas à propriedade privada, com os quais entrou em contato por conta dos embates dados na atuação jornalística. $O$ debate com os comunistas aparece registrado pela primeira vez num artigo de polêmica com o socialista Moses Hess sobre o que. de fato. deveria ser uma dissolução do Estado. Posteriormente, num artigo de resposta à Gazeta de Augsburg, Marx expressou sua atenção ao comunismo mais propriamente como um flerte e como defesa da necessidade de se debater mais seriamente os movimentos comunistas que então surgiam na Europa. Em outro momento, no artigo de crítica às resoluçóes da

\footnotetext{
${ }^{1}$ Doutora em Filosofia pela Universidade de São Paulo (USP), São Paulo, SP - Brasil. (D) https:// orcid.org/0000-0001-6804-3742 E-mail: lemos.julia@gmail.com

Pós-doutoranda na área de Filosofia Política e Ética da Faculdade de Filosofia da Universidade Federal de Goiás. Autora dos livros Dinâmica dos fatores estruturais em Marx (Kelps, 2014) e Caminhos da liberdade no Jovem Marx (Anita Garibaldi, 2017).
}

http://dx.doi.org/10.1590/0101-3173.2019.v42n2.07.p123 
VI Assembleia da Província do Reno ${ }^{2}$, Marx expressou tal atenção como um engajamento no questionamento à propriedade privada como fundamento do Estado. Demonstraremos que o movimento de Marx que perpassa esses três ensaios ocorre de modo a fazê-lo esbarrar cada vez mais efetivamente no problema fundamental que Hegel já indicara, quando se opôs à democracia: a gravidade do moderno domínio da propriedade privada livre e do interesse privado, em detrimento do interesse geral.

\section{Ponto de Partida: InfluênCias de Rousseau}

Em sua "Crítica ao Editorial do no 179 da 'Gazeta de Colônia”, redigida contra um teólogo kantiano chamado Heinrich Hermes, o jovem Marx se apresentou aqui como um herdeiro crítico das teorias modernas de Estado, afirmando que as revoluçóes europeias seriam justamente uma aplicaçáo da filosofia moderna, no âmbito do Estado, mas não uma aplicação completamente perfeita. Marx citou, nesse mesmo artigo, os filósofos que inspiraram o que ele chama de Estado racional: "Primeiro Maquiavel e Campanella, mais tarde Hobbes, Espinosa, Hugo Grotius, até Rousseau, Fitche e Hegel.” (MARX, 1975d, p. 42, tradução nossa). O teólogo Hermes deveria lembrar-se, diz Marx (1975d, p. 42), o fato de que o Código Civil Prussiano também "saiu desse lobo", mas que isso demonstraria apenas que algumas filosofias/Estados da modernidade são menos profundas que outras.

Mas se os professores de direito constitucional de outrora construíram o Estado a partir dos instintos, quer da ambição, quer da sociabilidade, ou, claro, a partir da razão, mas não da razão social e sim a partir da razão do indivíduo, pois bem, a concepçáo da filosofia moderna mais profunda deduz o Estado da ideia do todo. Ela considera o Estado como o grande organismo no qual as liberdades jurídica, moral e política devem-se realizar e no qual cada cidadáo, obedecendo às leis do Estado, está a obedecer às leis naturais da sua própria razão, da sua razão humana. (MARX, 1972b, p. 43).

Ao se contrapor a Hermes, Marx explicita claramente que o seu posicionamento é simultaneamente hegeliano e crítico de Hegel, republicano e

${ }^{2}$ Comments on the latest prussian censorship instruction, publicado pela primeira vez em 10 de janeiro de 1842, no Anekdota zur neuesten deutschen Philosophie und Publicistik, e, pela segunda vez na Gazeta Renana, em 15 de fevereiro do mesmo ano. O termo "filisteu" é comumente usado por Marx para se referir aos burgueses burocratas do Estado ou simplesmente aos prussianos conformados com o absolutismo. 
crítico do regime vigente. Marx defende o todo como o verdadeiro fundamento racional do Estado, não em termos de ideia e sim de determinação de todos. O Estado é uma associação livre de seres morais: "Onde encontra Hermes a prova de que o Estado é um Estado cristão, que sua finalidade é, em vez de uma associação livre de seres morais, uma associação de crentes, em vez da realização da liberdade, a realização do dogma?” (MARX, 1972b, p. 44). Fica evidente aqui o tom rousseuaniano do Estado almejado pelo jovem Marx, na medida em que, nele, o Estado que realiza a liberdade na modernidade é o "grande organismo no qual as liberdades jurídica, moral e política devem-se realizar e no qual cada cidadão, obedecendo às leis do Estado, está a obedecer às leis naturais da sua própria razão" (MARX, 1972b, p. 43). Rousseau (2003, p. 20) defendera que, para solucionar a antinomia entre liberdade e vida social, é preciso: "Encontrar uma forma de associação que defenda e proteja com toda a força comum a pessoa e os bens de cada associado, e pela qual cada um, unindo-se a todos, só obedeça, contudo, a si mesmo e permaneça táo livre quanto antes." O tom rousseuaniano surge em Marx, em termos de um processo no qual a vontade individual não é forçada a submeter-se, dado que ela se identifica, de fato, com a vontade geral. A obediência às leis do Estado como forma de obediência à própria razão particular remete a Rousseau, quando se trata de uma pedagogia do processo de constituição do Estado que transforma a vontade individual em vontade geral:

A verdadeira educação "pública” do Estado reside, pelo contrário, na existência racional e pública do Estado. [...] é o próprio Estado que educa seus membros, fazendo deles verdadeiros membros do Estado, transformando os objetivos individuais em objetivos gerais, o instinto grosseiro em inclinação moral, a independência natural em liberdade intelectual, fazendo que o indivíduo se desenvolva na vida do conjunto e que o conjunto viva no espírito do indivíduo. O nosso editor [Hermes], pelo contrário, faz do Estado náo uma associaçáo de homens livres que se educam mutuamente, mas um rebanho de adultos destinados a receber a educação de cima. (MARX, 1972b, p. 44).

O Estado racional e público, para Marx, seria uma associação na qual os homens realizam sua liberdade, ou seja, não seria uma razão externa e hierarquicamente superior educando os homens de cima para baixo, contudo, um mediador na determinação mútua entre os homens. Ou seja, uma associação na qual eles se educam uns aos outros como seres menos individuais e mais sociais, na medida em que permite que "o indivíduo se desenvolva na vida do conjunto e que o conjunto viva no espírito do indivíduo" (MARX, 1972b, p. 
44). O Estado racional é aquele que realiza a liberdade não meramente formal, mas de modo real, dado o seu caráter eminentemente pedagógico: constituir o Estado é constituir a vontade geral. O fato de o jovem Marx explicitar uma teoria de Estado que remete a Rousseau ratifica o seu caráter eminentemente democrático, dado que Rousseau era partidário da democracia direta: nele, o poder soberano pertence ao povo unido, união que forma uma vontade geral a qual não pode ser transferida ou representada. É nesse sentido que se torna completamente factível tomar como ponto de partida a defesa de uma República essencialmente democrática, por parte do jovem Marx redator da Gazeta Renana.

\section{O DESENVOLVIMENTO do ESTAdo DEMOCRÁTICO COMO DisSOluÇÃo do EsTA- do (CRítica a Moses Hess)}

Se, no artigo contra Hermes, é possível identificar o tipo de Estado que Marx pretende, quando defende uma República Democrática, a referência de Estado democrático como dissoluçáo do Estado aparece pela primeira vez no primeiro texto em que ele critica o utopismo socialista, mediante uma contraposição a Moses Hess, em 5 de maio de 1842. Na ocasião, Marx indicou ser um idealismo unilateral tentar realizar uma dissoluçáo do Estado, dispensando o ato político de desenvolvimento do Estado racional. Colega de Marx na Gazeta Renana, Hess havia feito um artigo no qual tentara resolver a polêmica da centralizaçáo do poder prussiano num governo central do país, ressaltando que a polêmica era saber "se um único ponto deve governar ou se cada província deve administrar a si mesma e ao ato do governo central apenas externamente como o poder do todo 'em relação ao exterior'” (MARX, 1975e, p. 182, tradução nossa) e sugerindo que,

se o homem está de acordo com a sua essência, a liberdade individual não se separa da liberdade geral [...] Assim como toda lei externa em geral e cada instituição positiva etc., seria supérflua, também seria supérfluo qualquer poder central estatal etc. Tal sociedade não seria um Estado, mas uma humanidade ideal. (HESS, 1842, apud MARX, 1975e, p. 182, tradução nossa).

Hess defendeu que a polêmica sobre o tipo de Estado - centralizado ou descentralizado - deixaria de existir, táo logo o homem esteja de acordo com a sua natureza, já que, numa sociedade na qual o homem está de acordo com sua essência, as leis e instituiçóes de poder deixam de ser necessárias. 
Para Marx, Hess levanta a questão da necessidade do Estado como se tal fosse um desenvolvimento conceitual particular, enquanto, na verdade, tal questáo foi colocada pela história: "As questôes são vozes descompromissadas do tempo que abraçam os indivíduos", a "própria história mundial não tem outro método de resposta a não ser despojando-se de velhas questóes e colocando outras novas", e "a verdadeira crítica analisa as questôes e não as respostas [...] a solução de uma equação algébrica é dada uma vez que o problema foi colocado em sua forma mais simples e mais nítida, de modo que cada pergunta seja respondida tão logo se torne uma questão real." (MARX, 1975e, p. 182, tradução nossa). Assim, na medida em que dera a questão da centralizaçáo como desenvolvimento puramente conceitual, Hess também dera a solução dela como desenvolvimento puramente conceitual: nele, a dissoluçáo do Estado se daria pela via de realização de um humanismo já posto nos homens e não pelo desenvolvimento histórico do Estado:

$\mathrm{O}$ autor do artigo começa com uma autocrítica da sua questáo. Vista de um ponto de vista superior, esta não existe e, ao mesmo tempo, nos é dito que, desse ponto de vista superior, todas as leis, instituiçóes positivas e poder estatal centralizado e, finalmente, o Estado em si, desaparecem. $\mathrm{O}$ autor está certo em elogiar a "surpreendente facilidade" com a qual esse ponto de vista é capaz de orientar a si mesmo, mas ele não está certo em chamar tal solução dos problemas de "completamente correta", ou melhor, a "única correta”; ele náo está certo, sobretudo, de chamar esse ponto de vista de "filosófico". A filosofia deve protestar seriamente, por ser confundida com imaginação. A ficção de uma nação de pessoas "íntegras” é tão estranha à filosofia como a ficção de "hienas religiosas" é à natureza. O autor dá suas abstraçóes como filosofia. (MARX, 1975e, p. 183, tradução nossa).

Marx se contrapóe a Hess, afirmando que, em primeiro lugar, embora dissolver o Estado pudesse ser de fato uma soluçáo e talvez pudesse resolver a polêmica sobre qual seria a melhor forma de Estado, tal dissolução meramente conceitual não é completamente correta. Nesse sentido, é de fato surpreendente a facilidade com que Hess pensa poder solucionar o problema: ao invés de desenvolver concretamente o Estado, desenvolver o seu conceito em si mesmo. A solução de Hess à polêmica sobre a melhor forma de Estado seria idealista, não por propor a dissolução do Estado, mas por indicar tal dissolução como um ponto de vista que orienta a si mesmo, sendo este uma integridade já dada nos homens. Tal resolução seria uma especulação apenas imaginativa e não verdadeiramente filosófica, dado que a filosofia não é mero desenvolvimento do princípio por si mesmo, todavia, desenvolvimento das determinaçóes con- 
cretas do conceito, por meio da história. Assim, Marx empreende a defesa de uma abertura aos modos como as questóes podem ser resolvidas na história e a objeção à possibilidade de desenvolver o Estado apenas descobrindo o Estado ideal dentro da especulação conceitual.

Para além das discordâncias com o socialista Hess, o essencial a se reter é que Marx elogia a dissolução do Estado como importante questão colocada pela história e que os socialistas teriam tido o mérito de chamar a atenção para este fato. Assim, apesar de utópicos no modo moralista como propunham a resoluçáo da antinomia moderna, os socialistas traziam indagaçóes que deviam ser levadas a sério. Isso também se confirma num artigo posterior, "Sobre o Editorial 284 da Gazeta Geral Augsburg” (MARX, 1975e). Nele, fica evidente que Marx há algum tempo já estava bastante interessado pelas ideias comunistas e que havia começado a dar mais atenção para o problema do domínio da propriedade privada. Tal problema já tinha sido levantado por Rousseau como princípio da desigualdade e da perda da felicidade original, mas, em Hegel, havia se transformado numa justificativa do absolutismo.

\section{O Problema da PROPRIEdAde PRIVAdA EM Hegel}

$\mathrm{Na}$ verdade, o interesse de Marx pela questáo da propriedade privada vinha completamente ao encontro com seu projeto de superação do Hegel idealista e absolutista. $\mathrm{O}$ combate à propriedade privada que os socialistas defendiam fora justamente o mote essencial de Hegel, na sua refutação à democracia. $\mathrm{O}$ desenvolvimento da cisão entre liberdade subjetiva e liberdade objetiva, para o qual Hegel buscara uma unidade madura, era justamente o desenvolvimento do domínio da propriedade privada livre, conforme explica Arantes (1999, p. 10):

A forma verdadeira da realidade, para Hegel, é a razão onde todas as contradições sujeito-objeto se integram, constituindo, desse modo, uma unidade e uma universalidade genuínas. Com os eventos de 1789, todos os homens haviam sido declarados livres e iguais; todavia, ao agir de acordo com seu conhecimento e em função de seus interesses, os homens haviam criado e experimentado uma ordem de dependência, de injustiça e de crises periódicas. A competição geral entre sujeitos economicamente livres não havia estabelecido uma comunidade racional que pudesse salvaguardar e satisfazer as necessidades e os interesses de todos os homens. A vida dos homens fora sacrificada aos mecanismos econômicos de um sistema social que relacionara os indivíduos uns aos outros como compradores e vendedores isolados de mercadorias. Essa ausência, de fato, de uma 
comunidade racional era responsável pela busca filosófica da unidade e da universalidade da razão.

Para Hegel, a constituição política da liberdade de competição desenfreada entre os homens não era ainda a constituição de uma comunidade plenamente racional, e é nesse sentido que a Monarquia Constitucional Prussiana seria um avanço em relação à República Francesa. ${ }^{3}$ Desai (2003) argumenta que Hegel concordara com Adam Smith que uma comunidade moral poderia decorrer das paixóes humanas individuais, mas discordara que tais paixóes individuais pudessem resultar em bem comum, sem que elas fossem desenvolvidas em um Estado soberano mediador:

O problema enfrentado por Hegel era quase precisamente o mesmo abordado pelos pensadores ingleses e escoceses do princípio do século XVIII. A época em que tinham vivido parecia sólida e firme. Mas agora se afastava e era fácil lembrar como tinha sido boa. Embora essa sociedade fosse contaminada pelo status, as pessoas cuidavam umas das outras [...] As relaçôes entre os indivíduos se baseavam em vínculos pessoais. Subitamente; o dinheiro estava subvertendo tudo isso [...] as relaçôes entre as pessoas se baseavam em um intercâmbio impessoal. Nesta situaçáo transitória, o que havia de sólido? [...] A resposta dada por Adam Smith era uma defesa e justificação quase agressiva do comércio e da impessoalidade das trocas. As relações entre as pessoas podiam parecer anônimas [...] Podem parecer autônomas e descoordenadas, mas parecem guiadas por uma mão invisível. [...] Para Adam Smith não havia como retornar ao passado; na melhor das hipóteses haveria um hiato de repouso em futuro estacionário. Hegel, porém, queria mais. Queria um melhor destino para a marcha para o progresso. [...] Hegel queria explorar os limites da individualidade autônoma e fundi-la com uma comunidade superior [...] Cada elemento da tríade família, sociedade civil e Estado tinha o seu papel a desempenhar na ordem racional. (DESAI, 2003, p. 49-50).

Assim, Hegel não concordou com Smith no que tange a uma completa espontaneidade moral, no sistema de competição livre. Este só desenvolveria as

\footnotetext{
${ }^{3}$ Hegel chegara a comemorar a Revoluçáo Francesa, por esta ter buscado engendrar, na prática, a racionalidade do Estado desenvolvida conceitualmente pela filosofia iluminista, contudo, defendera a Monarquia Constitucional como uma realização prática mais perfeita de tal racionalidade. Sobre isso, sua filosofia da história afirma que "o liberalismo dominou de modo especial em todas as naçôes latinas [...] mas por toda parte ele fracassou" (HEGEL, 1999, p. 370), argumentando que a "Revolução Francesa partiu da filosofia [...] mas essa filosofia é pensamento abstrato, não é compreensão concreta da verdade absoluta" (HEGEL, 1999, p. 343).
} 
paixôes individuais para o bem comum, num primeiro momento, mas, num segundo, haveria uma espécie de falência da "mão invisível", não realizada na forma de Estado. Ao contrário do que considerou Smith, a transposição das paixôes individuais ao bem comum exigia mediaçôes que limitassem a completa liberdade dos interesses privados. Trata-se de um posicionamento que, ao mesmo tempo, retoma Rousseau - a perda da ingenuidade do homem relacionada ao surgimento da propriedade - e, ao mesmo tempo, nega Rousseau - a possibilidade de liberdade apenas como imposiçáo da razáo como forma em si. Desai (2003) indica ainda que a oposição de Hegel à democracia fora uma espécie de oposição ao capitalismo desenfreado, por meio de um Estado que repusesse a racionalidade que a competitividade comercial destrói, sem, ao mesmo tempo, retroceder no progresso material. Nesse sentido, o filósofo foi inovador:

Hegel estava à frente de seu tempo. Sua oposição ao individualismo e à democracia representativa se baseava no vazio da liberdade individual abstrata. Na sua opiniáo, o povo precisa ser mais do que um conjunto de indivíduos livres e autônomos [...] O Estado precisava defender a sociedade civil - a economia de mercado - contra ela mesma, atendendo ao maior interesse. (DESAI, 2003, p. 53).

O Estado racional, em Hegel, portanto, seria aquele que atuaria de modo a prevenir a sobreposição do interesse individual, na sociedade. A realidade moderna expressava uma segregação do espírito desenvolvida que não permitia mais a democracia - unidade feliz - mas exigia a monarquia constitucional - unidade madura -, no sentido de que não cabia mais o retrocesso em relação ao desenvolvimento do individualismo. Ao salientar que a possibilidade de democracia ficara no momento de consciência infantil da razão e desaparecera para sempre, Hegel simultaneamente indicou a impossibilidade de revogação do sistema de propriedade privada numa República Democrática:

A ideia que a consciência forma habitualmente sobre a necessidade ou a utilidade da colaboração dos corpos legislativos é provavelmente a de que são os representantes do povo, ou antes, o próprio povo, quem deve compreender melhor do que ninguém o que de fato interessa ao seu próprio bem-estar e a de que é ele quem tem maior vontade de realizar esse bemestar. No que diz respeito ao primeiro ponto, o problema consistirá antes no fato de o povo - quando esta palavra designa uma determinada parte do Estado - constituir precisamente a parte que náo sabe o que quer. Saber o que se quer, ou melhor, o que quer a vontade em si e para si, a razão, é o fruto de um conhecimento profundo e de uma inteligência que não são 
características do povo. [...] As assembleias, que surgiram dos indivíduos, do ponto de vista privado e dos interesses particulares, inclinam-se a ter uma atividade a favor de si mesmas e a expensas do interesse geral. (HEGEL, 1821, apud MARX, 1983, p. 97).

Perdida a unidade espontânea entre interesse particular e interesse geral, a democracia tenderia a favorecer apenas os interesses particulares. $\mathrm{O}$ interesse geral é, para Hegel, a verdadeira racionalidade, mas, ao mesmo tempo, a única racionalidade que existe é sempre racionalidade particular. Dessa forma, o interesse geral só se pode impor de modo formal e mediante a soberania natural de um indivíduo. Daí a necessidade de diversas mediaçóes nas quais os interesses particulares diversos se subsumem ao interesse do monarca, como interesse geral: família, religião, classes e poderes políticos seriam momentos necessários no processo de submissão dos diversos indivíduos ao monarca. A questão da propriedade privada era central, por conseguinte, ao desenvolvimento hegeliano do Estado absolutista como Estado racional. Ao trazer à tona esse problema, os socialistas acabam por chamar bastante a atenção do Marx, o qual tentava subsumir a solução hegeliana por via da república democrática.

\section{A IMPORTÂNCIA DAS IDEIAS COMUNISTAS PARA O PROBLEMA DO INTERESSE PRIVADO}

Cinco meses após o artigo crítico ao socialista alemáo Moses Hess, Marx qualificou como essencial a reflexão que a perspectiva comunista desenvolvia, em torno da questão da propriedade privada. No artigo "Sobre o Editorial 284 da Gazeta Geral Augsburg", de outubro de 1842, ele se defende da acusação promovida pela Gazeta de Augsburg ${ }^{4}$ de que a Gazeta Renana teria um caráter comunista, argumentando que a revista não era comunista, mas abordava o comunismo, na medida em que este se apresentava como um fato não ignorável e levantava questôes extremamente importantes:

Que a profecia de Sieyes tenha se tornado verdade e que o terceiro Estado tenha se tornado tudo e queira ser tudo - tudo isso é reconhecido com a mais triste indignaçáo por Bulow - Cummerow, pelo último político berlinense, pelo Dr. Kosegarten e por todos os escritores feudais. Que a classe que hoje nada possui demande compartilhar riqueza da classe média é um fato, a despeito dos discursos de Estrasburgo e do silêncio da Gazeta de Augsburg, claramente reconhecido nas ruas de Manchester, Paris e Lyon.

\footnotetext{
${ }^{4}$ Editorial "As doutrinas comunistas" (Gazeta Geral de Augsburg, Colônia, n. 284, 1842).
} 
O Augsburg realmente acredita que a indignação e o silêncio refutam os fatos do momento? O Augsburg está numa fuga impertinente. Foge de questóes capciosas e acredita que a poeira que levanta e o barulho nervoso que murmura em seu voo podem cegar e confundir a desconfortável questão, assim como ao leitor incomodado. (MARX, 1975i, p. 222, tradução nossa).

Marx expressa nitidamente a sua tensão: nega um posicionamento comunista, ao mesmo tempo em que defende as questóes comunistas como intrigantes. Acusa a Gazeta de Augsburg de estar especialmente incomodada com o artigo da Gazeta Renana, pelo fato de este ter desnudado as ideias comunistas como ideias que "não cheiram a água de rosas", justamente depois que a própria Augsburg defendera que a monarquia se deveria apropriar da proposta comunista. ${ }^{5}$ Marx retoma a expressão utilizada por Danton, ${ }^{6}$ quando este defendera, num primeiro momento, o terror na Revolução Francesa - "as revoluções, meu caro, não cheiram a água de rosas" -, para sugerir que a Gazeta de Augsburg, que outrora admitira a importância europeia dos movimentos comunistas, na França e na Inglaterra, agora queria silenciar-se sobre as questóes comunistas, temendo o terror no qual elas poderiam desembocar. Mas, ao contrário do que desejava a Gazeta de Augsburg, o silêncio sobre o comunismo não poderia refutá-lo na prática. Marx se refere aqui ao fato de que era progressiva, nas províncias francesas, a efervescência do movimento comunista, o qual, desde 1839, sobretudo mediante o babouvismo e o neobabouvismo, ${ }^{7}$

5 "Então não devemos considerar o comunismo uma questão atual importante, pelo fato de não ser uma questáo com destaque privilegiado na corte, desde que tem uma roupagem suja e não cheira a água de rosas? Mas devemos concordar com a Gazeta de Augsburg. A importância do comunismo não descansa no fato de ser uma questão atual do momento mais elevado da França e da Inglaterra. O comunismo tem uma importância europeia, para repetir a frase usada pela Gazeta de Augsburg. Um de seus correspondentes em Paris, um convertido que trata a história da mesma forma que um cozinheiro de biscoitos trata uma planta, recentemente defendeu que a própria monarquia deveria buscar apropriar-se de ideias socialistas-comunistas. Agora podemos entender o desprazer do jornal Augsburg, o qual nunca irá nos perdoar por revelar o comunismo ao povo, em sua nudez não lavada." (MARX, 1975i, p. 3, tradução nossa).

6 Georges Jacques Danton, líder jacobino de grande destaque no processo inicial da Revoluçáo Francesa.

7 De acordo com Hobsbawm (1983, p. 40), o comunismo como movimento social moderno "tem início com a corrente de esquerda da Revoluçáo Francesa. Uma direta linha descendente liga a 'conspiração dos iguais’ de Babeuf, através de Felipe Buonarotti, às associaçôes revolucionárias de Blanqui dos anos 30; e essas, por sua vez, ligam-se - através da Liga dos Justos, formada pelos exilados alemães e inspirados por eles. [...] O comunismo babouvista e neobabouvista foi importante por dois motivos. Em primeiro lugar, ao contrário da maior parte das teorias dos socialistas utópicos, estava empenhado a fundo na atividade política e, portanto, não representava apenas uma teoria revolucionária, mas 
fortalecia-se enormemente entre os despossuídos, distinguindo-se de maneira explícita da esquerda dos republicanos liberais. Enfatizam os relatos posteriores de L. von Stein (1848, apud LÖWY, 2002, p. 115) ${ }^{8}$ :

Em todas as oficinas, em todas as habitaçōes dos operários, as ideias e teorias comunistas penetraram, e a agitação do que virá é comunicada ao mais insignificante dentre eles. É como se, desde a última revolta, o proletariado tivesse sentido que a partir de agora ele estava abandonado a si mesmo e devesse resolver por uma reflexão em comum suas difíceis tarefas.

No artigo "Sobre o Editorial 284 da Gazeta Geral Augsburg”, retomando o argumento da razão efetiva como razão popularmente determinada, outrora utilizado no artigo contra Hermes, Marx defende a necessidade de a filosofia compreender profundamente as ideias socialistas e ultrapassá-las objetivamente. Indica que as ideias dos socialistas mais profundos, como Leroux, Considerant e Proudhon, só podiam ser criticadas se compreendidas de um modo rigoroso:

A Gazeta Renana, que náo pode admitir a realidade teórica das ideias comunistas mesmo na sua forma presente, e pode menos ainda desejar ou considerar possível sua realização prática, irá submeter essas ideias a um pensamento crítico. Se a Gazeta Augsburg demanda e quer mais que frases rasas, deve ver que escritos como os de Leroux, Considerant e, sobretudo, o penetrante trabalho de Proudhon, ${ }^{9}$ podem ser criticados náo por meio das noçóes superficiais do momento, mas apenas depois de um estudo longo e profundo. (MARX, 1975e, p. 223, tradução nossa).

também uma doutrina (embora limitada) da práxis política, da organização, da estratégia e da tática. Seus principais representantes nos anos 30 [...] sobretudo Blanqui, eram ativos revolucionários. [...] Em segundo lugar, mesmo se os escritores comunistas eram em sua maioria intelectuais marginais, o movimento comunista exerceu uma evidente atração sobre os trabalhadores". Hobsbawm (1983, p. 41) também assinala que esse movimento francês adotou o nome "comunista", por volta de 1840: “O 'Premier Banquet Communiste’ foi realizado em 1840; o Comment je suis communiste e Mon crédo communiste, de Cabet, datam de 1841, Em 1842, L. von Stein - em Der Socialismus und Communismus des heutigen Frankreichs, bastante divulgado na Alemanha - tentava já, pela primeira vez, um nítida distinção entre os dois fenômenos."

${ }^{8}$ De acordo com Löwy (2002, p. 113), Lorenz von Stein promoveu, em seu Der Socialismus und Communismus des heutigen Frankreichs, uma análise sociológica, destacando a ascensão do comunismo desde 1840 como um movimento de massa que se desenvolvia rapidamente, a qual provavelmente fora estudada por Marx por volta de 1844-1845.

9 O destaque a Proudhon é relevante e a influência deste sobre Marx é expressa primeiramente no seu artigo "Sobre a lei do roubo de lenha", quando trata da linha tênue entre o roubo e a propriedade. Proudhon, o "mais penetrante" dentre os demais, havia publicado, em 1840, sua obra O que é a propriedade, na qual afirmara que "a propriedade é um roubo". 
As ideias socialistas deveriam ser refutadas, ainda que não fossem realizáveis. Exigiam um estudo profundo não pelo fato de "não cheirarem a água de rosas", porém, pelo perigo de não revogarem a monarquia, dado o caráter idealista que continham e dado o fato de não serem superficiais e, portanto, de serem apaixonantes, num âmbito devaneador. O risco maior seria deixar-se aprisionar por elas, deixar-se prender em projetos ineficazes para uma emancipação efetiva: a emancipação política. Tratava-se de superar o perigo da queda em resoluçóes abstratas e parciais que desviassem os homens da tarefa de desenvolvimento do Estado mais racional (democrático, no caso). O socialismo consistia num perigo mais por conta de seu idealismo que de sua prática: embora o movimento comunista fosse concretamente destruído, suas ideias de emancipar o homem sem passar pelo Estado se poderiam tornar cadeias contrárias a uma emancipação efetiva:

Estamos firmemente convencidos de que não é a tentativa prática, mas sim a aplicação teórica das ideais comunistas que constituem um perigo real; as tentativas práticas, mesmo as de mais larga escala, podem ser respondidas com canhóes, tâo logo se tornem perigosas, mas as ideias, que conquistam nossa inteligência, que superam a perspectiva que a razão alcançou em nossa consciência, são cadeias das quais náo podemos nos livrar sozinhos, sem libertar nossos coraçóes; elas são demônios os quais o homem pode vencer apenas submetendo-se a elas. (MARX, 1975 e, p. 223, tradução nossa).

Para Marx, as ideias socialistas eram perigosas porque capazes de envolver os homens em ideais irrealizáveis e desviá-los do real caminho de emancipação, a luta política. Ele estava convicto de que o desenvolvimento da liberdade só seria possível com o desenvolvimento da forma de determinação da razão pública numa República Democrática, e as sociedades dos socialistas eram paralelas, não tinham a revolução política como foco de seus interesses. Sem o desenvolvimento do Estado, náo haveria o desenvolvimento efetivo da liberdade.

Marx indica aqui o trabalho de Proudhon como o mais penetrante. Coincidentemente, Proudhon desenvolvera uma crítica à propriedade privada e ao Estado Republicano, tal como Hegel, ainda que de modo completamente distinto deste. ${ }^{10}$ A necessidade de superar as teorias comunistas utópicas se

\footnotetext{
${ }^{10}$ Contraposto a qualquer forma de propriedade, defendia uma reforma que tornasse todos os homens trabalhadores assalariados. Esta deveria levar ao não Estado absoluto, sendo diferente, portanto, da soluçâao hegeliana de desenvolvimento do Estado absoluto baseado no morgadio, propriedade agrária extensa de tradição familiar.
} 
mistura aqui com a tarefa de subsumir os argumentos hegelianos de contraposição à democracia. Como veremos, no artigo "Sobre a lei do roubo de lenha" (MARX, 1975j), publicado no final daquele mesmo ano, 1842, Marx defenderá o seu projeto de desenvolvimento da República Democrática num caráter notavelmente diferenciado do feito até então: trazendo a argumentação, de tom proudhoniano, contra a propriedade privada. É certo, portanto, que antes mesmo de redigir sua crítica à legislação prussiana sobre o roubo de lenha, ele já cumpria a tarefa que anunciou necessária à filosofia: estudava profundamente os escritos dos socialistas utópicos, sobretudo "o penetrante trabalho de Proudhon" (MARX, 1975i, tradução nossa).

\section{A obra penetrante de Proudhon}

Proudhon assinala que o mal foi concebido como eterno e não ultrapassável, tanto no campo religioso quanto no campo materialista. Para ele, o materialista Destutt De Tracy "ensina formalmente que a miséria, os crimes, a guerra são a condição inevitável do nosso estado social, um mal necessário contra o qual seria loucura revoltar-se" (PROUDHON, 1975, p. 21). Entretanto, De Tracy estaria equivocado: "Há progresso contínuo do gênero humano para a verdade e triunfo da luz sobre as trevas. $\mathrm{O}$ nosso mal não é, pois, perfeitamente incurável [...] Ora, se o homem conseguiu instruir-se de tudo o que necessita saber, acreditamos que, não se enganando mais, deixará de sofrer." (PROUDHON, 1975, p. 21). O ponto de partida de Proudhon é a consideração de que existe um bem absoluto e verdadeiro e que tal bem é a justiça, de maneira que, historicamente, é a justiça que os homens exaltam a todo tempo. Assim, os homens já sabem que a justiça é o bem absoluto, entretanto, limitam-se a exaltá-la, sem de fato descobrir sua ciência e acabam por fazer leis para estabelecer a justiça, sem compreender que é preciso, antes, fazer das leis uma aplicaçáo da ciência do justo:

\footnotetext{
A justiça é o astro central que governa as sociedades, o polo sobre que o mundo político gira, o princípio e regra de todas as transaçóes. Entre os homens nada se faz que não seja valorizar o direito invocando a justiça. A justiça não é obra da lei, pelo contrário, a lei é apenas a declaraçáo e a aplicação do justo em todas as circunstâncias em que os homens se possam encontrar relacionados. Portanto se a ideia que nós fazemos do justo e do direito estivesse mal determinada, se fosse incompleta ou mesmo falsa, é evidente que todas as nossas aplicações legislativas seriam más, as instituiçóes viciosas, a política errada: daí adviriam a desordem e mal social. (PROUDHON, 1975, p. 23).
} 
A hipótese de Proudhon é a de que, sem a avançada compreensão da justiça, no plano conceitual, não será possível empreender leis justas: a perversão da justiça, em nosso entendimento, teria como consequência a perversão da justiça em nossos atos. Seria prova dessa hipótese o fato de a palavra de Deus ter transformado Roma, ${ }^{11}$ mas náo ter estabelecido completamente a justiça, e o fato de a brochura de Sieyès sobre o terceiro Estado ter desenvolvido na França uma queda do absolutismo que não necessariamente estabeleceu a justiça efetiva:

O povo hesitava por seus direitos, até que apareceu um livro "que se resumia a duas proposiçóes: $\mathrm{O}$ que é o terceiro estado? Nada. - O que devia ser? Tudo. Alguém acrescentou, em forma de comentário: o que é o rei? É o mandatário do povo. Foi como uma revoluçâo súbita: rasgou-se um véu imenso, de todos os olhos caiu uma venda espessa. $\mathrm{O}$ povo se pôs a raciocinar [...] Cinco anos depois da publicação da brochura de Sieyès, o terceiro estado era tudo, o rei, a nobreza e o clero já nada valiam. Em 1793 o povo, sem se prender com a ficção constitucional da inviolabilidade do soberano, conduziu Luís XVI ao cadafalso, em 1830 acompanhou Carlos $\mathrm{X}$ a Chesburgo. [...] [Entretanto] o espírito que originou o movimento de 89 foi um espírito de contradição; isso bastou para demonstrar que a ordem que substituiu a antiga nada teve de metódico e refletido; que nascida da cólera e do ódio, não podia ter o efeito de uma ciência formada na observaçáo e no estudo; numa palavra, que as bases não eram deduzidas do conhecimento profundo das leis da natureza e da sociedade. Vê-se, assim, que, nas instituiçóes ditas novas, a república se serviu dos mesmos princípios contra os quais combatera e sofreu a influência de todos os preconceitos que tivera intenção de banir. Fala-se com entusiasmo irrefletido da gloriosa Revolução Francesa, da regeneração de 1789, das grandes reformas operadas, da modificação das instituiçóes: mentira! Mentira!” (PROUDHON, 1975, p. 25-26).

Proudhon nega o caráter revolucionário da passagem da monarquia absolutista à república democrática. Para ele, os acontecimentos de 1789, na França, não foram exatamente revolucionários, por não terem alterado o fundamento das instituiçóes. Ainda que a passagem da monarquia à república fosse um avanço, tratava-se de um avanço meramente formal, o qual não efetivava a liberdade dos homens:

\footnotetext{
11 "A sociedade foi salva pela negação dos seus princípios. [...] A justiça tinha existido apenas para os senhores, começou desde então a existir para os servos. No entanto, a nova religiáo esteve longe de dar todos os seus frutos." (PROUDHON, 1975, p. 24-25).
} 
Em 1789 houve luta e progresso, não houve revolução. A análise das reformas experimentadas assim o demonstra. [...] Sem dúvida que há progresso sempre que um povo passa do estado monárquico ao democrático, porque, fraccionando o poder, oferecem-se maiores oportunidades de a razão substituir-se à vontade, mas afinal não há revolução no governo visto que o princípio continua a ser o mesmo. Ora, hoje mesmo temos a prova de que não se pode ser livre na mais perfeita democracia. (PROUDHON, 1975, p. 27).

A verdadeira e necessária revolução, para Proudhon, tratava-se, assim, de uma revolução no conceito. A impossibilidade de realização da razão pela democracia havia ficado demonstrada pelo modo como esta, como a monarquia, estabeleceu não a lei de acordo com a justiça racional de fato, mas ainda de acordo com a mera vontade:

A lei, dizia-se, é a expressão da vontade do soberano: portanto, sob uma monarquia, a lei é a expressão da vontade do rei, numa república a lei é a expressão da vontade do povo. À parte a diferença do número de vontades os dois sistemas são perfeitamente idênticos, num e noutro o erro é igual: fazer da lei a expressão de uma vontade, enquanto deve ser a expressáo de um fato. Contudo se seguiam bons guias: tomarase por profeta o cidadão de Genebra e o Contrato Social por Alcorão. (PROUDHON, 1975, p. 28).

Proudhon refuta diretamente a defesa da soberania do povo empreendida por Rousseau: tanto o rei quanto o povo náo poderiam constituir leis que expressassem a justiça, de fato, e sim as meras vontades. Ocorre que a vontade do povo copia a vontade dos soberanos: são os interesses de propriedade. Os novos legisladores declararam: "Todos os homens são iguais por natureza e à face da lei." Mas tal declaração seria não só "ambígua e redundante", na medida em que "é então a igualdade política que se quer designar", como ainda indefinida, já que não há igualdade política sem igualdade social:

Mas o que é a igualdade perante a lei? Nem a Constituição de 1790, nem a de 93, nem a carta outorgada nem a carta aceite souberam definir. Todas nos legaram uma desigualdade de riqueza e casta ao lado da qual era impossível encontrar a sombra de uma igualdade de direitos. Sob este ponto de vista, pode-se dizer que todas as nossas constituiçóes foram a expressão fiel da vontade popular: vou prová-lo. (PROUDHON, 1975, p. 29). 
De acordo com Proudhon, a declaração de igualdade política foi simultaneamente uma declaração de desigualdade econômica, e tal foi expressão da própria vontade do povo. Quem julgou que equivocadamente a igualdade política se constituiria em igualdade real foi justamente o povo. Proudhon ressalta, dessa forma, que a vontade popular é ineficiente para estabelecer o justo de fato. Na verdade, o problema é que também o povo permanecia contaminado por um princípio medieval de justiça:

Sob este ponto de vista, pode-se dizer que todas as nossas constituiçóes foram a expressão fiel da vontade popular: vou prová-lo. [...] O povo foi imitador dos reis: quis dispor de lugares lucrativos em favor dos amigos e aduladores. [...] Este artigo edificante da Declaração dos direitos supóe várias espécies de desigualdades civis, o que significa desigualdades perante a lei: desigualdade de castas [...] desigualdade de riquezas [...] desigualdade de merecimento [...]. Por fim, o povo consagrou a propriedade... Deus the perdoe, porque ele náo sabia o que fazia. [...] Mas como é que o povo pode se enganar? [...] Sempre por imitação do regime antigo. O povo quis que a condição de proprietário fosse igual para todos. [...] As formas acerbas de propriedade [...] foi modificado: conservou-se o fundo. [...] Houve progresso na atribuição de direito; não houve revolução. (PROUDHON, 1975, p. 28-29, grifo do autor).

Proudhon coloca em questão a referência de revolução quanto à mera alteração da forma política, indicando claramente que a verdadeira revolução não é uma alteração (ampliação) do direito de propriedade, mas a revogaçáo da propriedade como um direito. Nesse sentido, a República não seria uma estrutura revolucionária em relação à Monarquia, porque mantinha a propriedade como fundamento da vontade soberana das leis, embora tal vontade partisse do povo. Ao invés de desenvolver a democracia, portanto, era preciso inverter conceitualmente o princípio moderno de justiça - a propriedade para encontrar a justiça efetiva:

Eis três princípios fundamentais da sociedade moderna que os movimentos de 1789 e 1830 consagraram: $1^{\circ}$ - Soberania da vontade do homem e, reduzindo a expressão, despotismo; $2^{\circ}$ - Desigualdade de riquezas e castas; $3^{\circ}$ - Propriedade: acima da Justiça. [...] Ter-se-á de saber se os conceitos de despotismo, desigualdade civil e propriedade estáo ou não em conformidade com a noção original do justo, se são uma dedução necessária dela [...] ou se serão antes o produto ilegítimo de uma mistura de coisas diferentes. (PROUDHON, 1975, p. 30, grifo do autor). 
Por conseguinte, para descobrir se a sociedade moderna está de acordo com a justiça efetiva, é preciso recusar a compreensão de que a justiça está dada já na vontade do povo, já que o povo também consideraria justa a propriedade: "É justa a propriedade? Toda gente responde sem hesitar: sim, a propriedade é justa." (PROUDHON, 1975, p. 32). Na contramão do que pensa a maioria, Proudhon pretende demonstrar que a propriedade não é justa, num desenvolvimento conceitual para encontrar o que é verdadeiramente justo. E, a partir da refutaçáo ao princípio de propriedade dado, o princípio da verdadeira justiça seria encontrado. Ele anuncia sua tarefa do seguinte modo:

Recorrendo à psicologia e analisando a fundo a natureza do homem, exporemos o princípio do justo, a sua fórmula, o seu caráter, precisaremos a lei orgânica da sociedade, explicaremos a origem da propriedade, as causas de seu estabelecimento, longa duração e próximo desaparecimento, estabeleceremos o seu paralelo com o roubo; e depois de ter mostrado que esses três preconceitos, soberania do homem, desigualdade de condiçōes, propriedade, náo são mais do que um, que podem ser tomados pelo outro e são reciprocamente convertíveis; náo teremos dificuldade em deduzir pelo princípio da contradição, o fundamento do poder e do direito. Aí pararão as nossas pesquisas. (PROUDHON, 1975, p. 33).

A obra $O$ que é a propriedade seria, para Proudhon, uma demonstração de que os três princípios da sociedade moderna são um só - o princípio do interesse de propriedade - e que esse princípio único é injusto. Deveria ser evidenciado que a propriedade é um roubo - o exato oposto de justiça - e que, portanto, é justamente na inversão desse princípio de propriedade que estaria a verdadeira justiça e, pois, o verdadeiro fundamento do poder e da lei. Logo, a revolução é sobretudo conceitual: "Chamo de revolução a esse movimento do espírito" (PROUDHON, 1975, p. 27), e não a alternância da forma monárquica para a forma democrática. Proudhon (1975, p. 29) considera que a passagem do absolutismo para a democracia seria uma mera reforma no modo de domínio da propriedade e que "o único obstáculo que resta vencer para acabar a reforma do governo e consumar a revoluçáo deriva unicamente da instituição do domínio de propriedade que conservamos, é essa instituição que devemos atacar". Assim, toda a transformação moral e social depende do conhecimento sobre o problema da propriedade: "É da questão de saber se a propriedade é o princípio ou o resultado da ordem social, se é preciso considerá-la como causa ou como efeito, que depende toda a moralidade e, por isso mesmo, toda a autoridade das instituiçóes humanas." (PROUDHON, 1975, p. 33). 
Ao final de sua obra, Proudhon é claro em sublinhar que o verdadeiro modo de emancipação dos homens perpassava não a transformação da forma de Estado, todavia, a reforma que generalizaria a todos os homens posses limitadas dos produtos do trabalho, generalizando a todos condição de trabalhadores assalariados. De tal reformulação econômica ocorreria a vitória do trabalho, a supressão da propriedade privada. Considerando que "o trabalho destrói a propriedade", Proudhon (1975, p. 33) afirma: "Suprimi a propriedade e conservai a posse; e, só com essa alteração no princípio, mudareis tudo nas leis, o governo, a economia, as instituiçóes: expulsareis o mal da terra." A reforma econômica deveria levar, mais especificamente, à própria abolição do Estado - ao invés de uma nova forma estatal. Para ele, "o governo do homem pelo homem, não importa o nome com que se disfarce, é opressão; a perfeição máxima da sociedade reside na união da ordem e da anarquia” (PROUDHON, 1975, p. 247), de sorte que era preciso construir uma organização social autogestionada, isto é, empreendida sem a intermediação do poder do Estado e de suas instituiçóes, do que propriamente revolucionar o Estado da monarquia para a democracia.

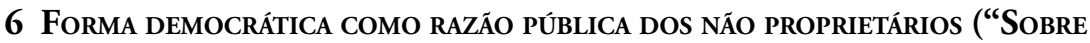 A LEI DO ROUBO DE LENHA")}

A leitura que Marx fez de Proudhon não implicou um abandono do projeto de luta por uma forma política democrática, mas deslocou a república democrática do lugar de fim em si da emancipação humana. Após estudar Proudhon, ${ }^{12}$ ao invés de combater as ideias socialistas sobre a propriedade ${ }^{13}-\mathrm{de}$ que a dissolução da propriedade privada era necessária para a emancipação dos homens - os artigos subsequentes ao "Sobre o Editorial 284 da Gazeta Geral Augsburg” (MARX, 1975i) desenvolverão a defesa da dissolução da proprieda-

\footnotetext{
${ }^{12}$ Para Hobsbawm (1983, p. 52), "afirmar que Proudhon influenciou Marx ou contribuiu para a formação do seu pensamento seria um exagero", dado que "Marx elogiou Proudhon não porque tivesse algo a aprender com ele, mas porque o viu como um pioneiro da 'crítica da economia política' que ele próprio entendia como a tarefa teórica fundamental”. Contrapomo-nos a Hobsbawm, nesse sentido, considerando antes que seria um exagero dizer que Proudhon não contribuiu para a formação do pensamento de Marx, diante da inegável presença de Proudhon, num artigo-chave para a virada de Marx para a crítica da propriedade privada. Além disso, quando Marx leu Proudhon, ele ainda não entendia a crítica da economia política como tarefa fundamental, embora com isso seja simplista afirmar que aquele se voltou à tal crítica por conta da leitura deste, dado que, no próprio campo do hegelianismo, havia também uma polêmica com o liberalismo smithiano.

${ }^{13} \mathrm{O}$ grifo se dá para destacar que Marx mantém sua crítica aos socialistas, no que tange às questôes políticas.
} 
de de modo cada vez mais central, no interior do projeto de desenvolvimento da democracia. Ou seja, Marx irá subsumir a reversão do domínio da propriedade privada no processo de emancipação política, alterando o seu projeto de emancipação humana. Tal desenvolvimento começa a se esboçar no artigo "Sobre a lei do roubo de lenha" (MARX, 1975j).

Como vimos, em outubro de 1842, Marx já se demonstrava crítico da perversidade dos interesses privados e do liberalismo burguês. Porém, no artigo "Sobre a lei do roubo de lenha" (SRL), ele se volta a uma crítica contundente e feroz dos proprietários privados. Estes são indicados aqui como portadores de uma alma "mesquinha, estúpida e egoísta" e, num tom nitidamente hegeliano, são afirmados como próprios da "pré-história" dos homens (MARX, 1975j, p. 260). No artigo SRL, Marx avalia que a VI Assembleia da Província do Reno (MARX, 1975i) expressou critérios de propriedade contraditórios, quando definiu as cláusulas da lei do roubo de lenha, na Prússia, os quais acabaram por revelar que o interesse que foi afirmado como público pela lei era, na verdade, o interesse particular dos proprietários privados rurais, os quais compunham uma minoria. Marx (1975j) ressalta que, ao instituir como roubo de lenha qualquer forma de recolhimento de madeira, sem diferenciar o ato de retirar essa madeira de uma árvore do ato de recolhê-la do chão, a Assembleia Prussiana dera como lei não os costumes populares - os quais tinham o hábito de atribuir como roubo apenas a retirada da madeira - e sim os costumes não populares. No que tangia aos costumes populares, as madeiras caídas no chão por obra da natureza não tinham dono, ainda que numa floresta privada. Ao igualar quem recolhe a madeira caída no cháo àqueles que cortam a árvore para tirar a madeira, a legislação teria generalizado o ato do roubo. Tal generalização teria tornado vazio de efetividade pública o próprio critério de roubo: "Aplicando a categoria de roubo de lenha onde não deveria ser aplicada, você também a exonera onde deveria ser aplicada." (MARX, 1975i, p.227).

Marx (1975i, p. 227) lança então um argumento de tom proudhoniano: o uso indiscriminado da categoria de roubo também permitiria o uso indiscriminado da categoria de propriedade e assim impossibilitaria a distinção entre roubo e propriedade privada: "Se toda violação de propriedade sem distinção, sem uma definição mais exata, é dada como roubo, não poderíamos dizer que toda a propriedade privada é um roubo?" Ele mostra que, na verdade, o que a lei do roubo de lenha desnudara nitidamente é que a única diferenciação entre a propriedade privada e o roubo se baseava apenas no fato de os 
proprietários privados de terra serem os legisladores, de maneira que o critério para uma apropriação tornar-se ilegal era simplesmente a contrariedade aos interesses dos proprietários/legisladores:

Eles não reconhecem a diferença de crime, quando isso aflige os interesses dos proprietários, mas a reconhecem quando esse reconhecimento os favorece. Trata-se, portanto, apenas dos interesses dos proprietários. A definição legal é boa, na medida em que me é útil, é útil quando me favorece. Mas essa mesma definição legal é supérflua, nociva, pouco prática tão logo seja intencionada a ser aplicada para acusar a base como um mero capricho teórico. (MARX, 1975j, p.260, traduçáo nossa).

Marx mostra que a lei revela que a propriedade privada da terra é legitimada não porque seja um bem em si, um bem de interesse público, porém, pelo fato concreto de esses proprietários privados serem os próprios legisladores. Referindo-se indiretamente a Kant, ele afirma que os costumes que legitimavam o direito na ocasião se tratavam, na verdade, não da razão prática universal e sim da razão prática particular dos proprietários privados. Para além de criticar o fundamento da lei, Marx sugere fortemente a necessidade de revertê-lo. $\mathrm{Na}$ contramão da redução do direito à razão prática particular dos proprietários, era preciso requerer o direito consuetudinário, a partir da razão prática mais universal, a qual era a razão prática dos não proprietários:

Nós, pessoas pouco práticas, no entanto, requeremos para os pobres, para os sem propriedade socialmente e politicamente, muito mais que os sábios e estudiosos, os táo reconhecidos historiadores, descobriram ser a verdadeira pedra filosofal para transformar todo argumento sórdido em puro ouro da justiça. Requeremos para os pobres um direito consuetudinário de fato, não simplesmente de caráter local, mas um direito consuetudinário de todos os pobres, dos pobres de todos os países. Vamos muito mais longe; insistimos que um direito consuetudinário por sua própria natureza pode ser apenas o direito da massa humilde, despossuída e fundamental. Os chamados direitos consuetudinários das classes privilegiadas deverão então ser entendidos como costumes contrários à lei. (MARX, 1975j, p. 263, tradução nossa).

A crítica de Marx aos proprietários rurais surge aqui de um modo bastante radical, num tom diferenciado dos artigos anteriores. Não se trata somente de criticar o conservadorismo político dos proprietários rurais, contudo, de reivindicar uma nova fundamentação constitucional, pautada numa nova compreensão de amplitude dos costumes nos quais se baseia o direito 
consuetudinário. Tais costumes devem ser os mais universais possíveis e, portanto, abranger não só os despossuídos locais, mas todos os despossuídos. Era preciso ser rigoroso com o critério de universalidade do direito consuetudinário e, nesse rigor, os costumes até então dados como legítimos pela lei se tornariam ilegais, pelo fato de ferirem os costumes do direito consuetudinário verdadeiro: os costumes da ampla maioria efetiva. Marx não rejeita a lógica do direito dado, entretanto, leva em conta o próprio preceito de universalidade afirmado pelo direito consuetudinário: efetivar como lei geral os costumes gerais dos homens. Ao mesmo tempo, ele empreende uma crítica direta ao universalismo kantiano, portador de um direito consuetudinário vazio: não era o caso de defender a razão prática universal no conceito em si, mas de defendê-la efetivamente, a partir dos costumes efetivos de todos. Dado que tais costumes são contrários aos interesses dos proprietários privados, a verdadeira razão prática universal era a razão prática dos despossuídos. Numa clara inspiração hegeliana, Marx enfatiza que regulamentação fundada nos costumes dos despossuídos é que desenvolveria a saída dos homens da pré-história humana (ou, simplesmente, história natural) e a passagem para a história humana:

Insistimos que um direito consuetudinário por sua própria natureza pode ser apenas o direito da massa humilde, despossuída e fundamental. Os chamados direitos consuetudinários das classes privilegiadas deverão então ser entendidos como costumes contrários à lei. A origem destes remonta ao período em que a história humana era parte da história natural, e na qual, segundo a lenda egípcia, todos os deuses se escondiam sob a forma de animais. A humanidade parecia perdida em espécies definidas de animais, as quais foram conectadas não pela igualdade, mas pela desigualdade, desigualdade fixada por leis. Num mundo cuja condiçáo é a falta de liberdade, são necessárias leis que exprimam essa falta de liberdade; enquanto o direito humano é um modo de existência da liberdade, a lei animal é um modo de existência da não liberdade. (MARX, 1975j, 260, tradução nossa).

Marx toma o humanismo como horizonte histórico, assinalando que um direito consuetudinário verdadeiramente humano é aquele contrário aos interesses dos proprietários privados e a favor dos pobres e despossuídos. Esse direito teria um conteúdo humano em contraposição ao que defendem os proprietários, na medida em que este último se teria originado num momento em que os homens se uniram submetidos a uma relação animalesca (adoração dos animais) de desigualdade e não de igualdade. A desigualdade seria assim um momento animalesco dos homens e estaria anterior à história 
propriamente humana, distinta - e que subsume - à história natural, visto que a desigualdade é também o momento da não liberdade. Se o verdadeiro humanismo só se pode dar na realização da liberdade, só se pode fundar na relação de igualdade. Portanto, a lei fixada no momento da desigualdade deveria ser revogada. A distinção de Hegel entre história natural e história humana dos homens é retomada num modo distinto do projeto hegeliano, realçando que as classes privilegiadas reivindicam um direito consuetudinário animal e não um direito humano:

Quando as classes privilegiadas recorrem ao direito legal para fazerem valer seus direitos costumeiros, elas demandam náo o conteúdo humano do direito, mas sua forma animal, a qual perdeu sua realidade e se tornou mera máscara animal. [...] os chamados costumes da classe privilegiada devem ser entendidos como costumes contrários à lei. Sua origem data de um período no qual a história humana é parte da história natural [...] A humanidade aparece como rebaixada a uma espécie de animal que está interligada não pela igualdade, mas pela desigualdade, uma desigualdade fixada pelas leis. A condiçáo mundial de náo liberdade requereu leis que expressassem essa não liberdade, onde a lei humana é modo de existência da liberdade, essa lei animal é modo de existência da não liberdade. (MARX, 1975j, 261, tradução nossa).

Sendo uma espécie de resquício da história animal dos homens, a lei que fixa os interesses dos proprietários também estaria fixando uma forma de vida animal. Seria um paradoxo: na modernidade, os homens se afirmam humanos (livres), fixando formas de vida animal (não livre). $\mathrm{O}$ direito dos pobres, mesmo que não fixado ainda em lei, é que estaria de acordo com o fim do direito racional: realizar a liberdade dos homens.

O fim do direito racional é, propriamente, a constituição das leis como a liberdade dos homens, o contrário do que as leis positivas costumeiramente instituem. Portanto, ao se opor às leis positivas, o direito costumeiro dos pobres é propriamente o que está de acordo com o que seria um direito racional. Sendo o direito costumeiro dos pobres o verdadeiro conteúdo da liberdade dos homens, então o conteúdo do direito racional ainda não adquiriu forma legal. É preciso pouco raciocínio para perceber o quão unilateral a legislaçâo iluminista tem tratado e tem sido compelida a tratar os direitos costumeiros dos pobres, da qual os vários direitos germânicos podem ser considerados a fonte mais prolífica. (MARX, 1975j, 261, tradução nossa). 
A crítica ao modo como os Iluministas vinham tratando a questão dos pobres é objetiva. Unilaterais, estes não apreendiam os interesses dos pobres, tal como deveriam, como a verdadeira matéria da liberdade dos homens, como o verdadeiro conteúdo que deveria ser fixado pelo direito racional. Existiriam assim dois direitos: o direito animal, que era o direito positivo que fixara como lei os costumes dos proprietários privados, e o direito racional, baseado nos costumes dos despossuídos, a ser fixado em lei. Portanto, o direito racional já existe, apenas não tomou forma efetiva ainda:

Enquanto os direitos costumeiros da aristocracia são direitos contrários à concepção do direito racional, os direitos costumeiros do pobre são direitos contrários aos costumes da lei positiva. Seu conteúdo não entra em conflito com a forma legal, mas, sobretudo, com sua própria falta de forma. A forma da lei não está em contradição com o seu conteúdo, ao contrário, o último é que ainda não alcançou essa forma. (MARX, 1975j, 263, tradução nossa).

Ou seja, dado que a maioria é não proprietária, o interesse contrário à propriedade privada é que seria a razão pública efetiva, ao passo que o costume dos proprietários privados fixado na lei seria uma razão pública fictícia, a qual só possui status de público, tal como uma máscara, num sentido somente formal. A reapropriação de Proudhon é nítida aqui: de fato, a verdadeira justiça é a reversão do domínio da propriedade e já existe no plano conceitual. O direito realmente racional já foi determinado, mas sua efetivação depende não só desse desenvolvimento unilateral do conceito, como também da política. Ele precisa tomar a forma da lei.

A defesa dos interesses contrários ao interesse dos proprietários privados como verdadeiro interesse público não implica aqui, portanto, um abandono do projeto de desenvolvimento de uma democracia política em prol dos caminhos dos socialistas utópicos. Mas Marx subsume um projeto no outro: ao desenvolver a democracia, o interesse da maioria despossuída acabaria por se fixar como lei. A democracia política permanece assim necessária. Ocorre que o seu fim, a realização da liberdade, torna-se agora elaborado em termos de um percurso concreto: deve fazer a racionalidade pública efetiva - costumes contrários ao interesse de propriedade - adquirir o status de razão pública, no lugar da razão privada formalmente pública - costumes dos proprietários que até então está fixada pela lei. A democracia continua sendo a dissolução do privilégio do poder legislativo, até então concentrado na classe dos proprietários privados - mas, para além disso, ela deve levar também à dissolução do 
direito positivo, fixando o interesse público como interesse dos não proprietários privados.

Essa perspectiva será ainda mais profundamente desenvolvida num outro artigo de Marx, na "Crítica da filosofia do direito de Hegel" $(C F D H) .{ }^{14}$ A análise da legislação do roubo de lenha explicitara, para ele, que o interesse dos proprietários agrários só fora afirmado como público pelo fato de tais proprietários serem os únicos legisladores, deixando nítida a falsidade da solução de Hegel, quando este dera uma equivalência natural entre o interesse do proprietário privado agrário e o interesse público.

VIEIRA, J. L. The problem of private property for the young Marx. Trans/form/ação, Marília, v. 42, n. 2, p. 123-150, Abr./Jun., 2019.

\begin{abstract}
AвSTRACT: Through his study of the utopian socialists, and especially of Proudhon, the problem of the perversion of the social community by private property became quite clear to Marx: if private property - and the split between private interest and general interest originating from it - it is not a necessary development, but an incidental one, it can be subsumed. This article aims to demonstrate how, in search of a Rousseauian republicanism and a critique of bourgeois liberalism, Karl Marx flirted with the communists' critique of private property. We discuss Proudhon's critique of private property and five articles Mark wrote for the Rheinische Zeitung: the article against the Kantian Hermes, the controversy with the socialist Moses Hess, the reply to the Augsburg Allgemeine Zeitung, the critique of the resolutions of the Sixth Rhine Province Assembly, and the "Debates on the Law on the Thefts of Wood".
\end{abstract}

KeYwORDS: Marx. Proudhon. State property. Democracy.

\title{
REFERÊNCIAS
}

ARANTES, P. E. Hegel vida e obra. São Paulo: Nova Cultural, 1999. (Os Pensadores).

BAUER, B. Die Judenfrage. In: MARX, Karl. A questão judaica. Tradução de Wladimir Gomide. Rio de Janeiro: Laemert, 1969. (Original publicado em 1843).

\footnotetext{
${ }^{14} \mathrm{O}$ artigo no qual Marx analisa o sistema político hegeliano é conhecido sob diversos títulos: "Manuscritos de Kreuznach", "Crítica do Estado hegeliano", "Crítica da filosofia hegeliana do direito público" e "Crítica da filosofia do direito de Hegel". Iremos adotar o último, referente à tradução de que fazemos uso, sob a abreviatura CFDH. Ela foi publicada integralmente somente em 1927, por Riazanov, na edição do Instituto Marx-Engels de Moscou (LÖWY, 2011, p. 20).
} 
BERLIN, I. Karl Marx: his life and environment. 4. ed. New York: Oxford University Press, 1996.

COUTINHO, C. N. Crítica e utopia em Rousseau. Revista Lua Nova, São Paulo, n. 38, p. 5-30, dez. 1996. Disponível em: http://www.scielo.br/scielo.php?pid=S010264451996000200002\&script=sci_arttext\#nt. Acesso em: 24 mar. 2014.

DAL PRA, M. La dialéctica en Marx. Barcelona: Martínes Roca, 1971.

DELLA VOLPE, G. Rousseau e Marx: a liberdade igualitária. Tradução de Antonio José Pinto Ribeiro. Lisboa: Ediçóes 70, 1964.

DERATHÉ, R. L’homme selon Rousseau, em Pensée de Rousseau. Paris: Seuil, 1984.

DESAI, M. A vingança de Marx: a ressurgência do capitalismo e a morte do socialismo estatal. São Paulo: Códex, 2003.

HEGEL, G. W. F. Introdução à História da Filosofia. 2. ed. Tradução de Euclidy Carneiro da Silva. São Paulo: Hemus, 1980.

- Grundlinien der philosophie des Rechts. In: MARX, Karl. Critica da filosofia do direito de Hegel. Tradução de Conceição Jardim e Eduardo Lúcio Nogueira. Lisboa: Presença, 1983. (Original publicado em 1821)

. Filosofia da história. Tradução de Maria Rodrigues e Hans Harden. 2. ed. Brasília: Ed. UnB, 1999.

. Princípios da filosofia do direito. São Paulo: Martins Fontes, 2003.

. Phänomenologie des Geistes. In: HELFER, I. Hegel. In: PECORARO, R. (org.). Os filósofos: clássicos da filosofia, v. II: De Kant a Popper. Petrópolis, RJ: Vozes; Rio de Janeiro: PUC-Rio, 2008a. p. 57-82. (Original publicado em 1807).

HERMES, K. Editorial. Gazeta de Colônia, n. 179, 1842.

HESS, M. Deutschland und Frankreich in bezug auf die Zentralstionsfrage. Rheinische Zeitung, n. 137, 1842. In: MARX, Karl. The question of centralisation in itself and with regard to the Supplement to n. 137 of the Rheinische Zeitung. In: $M E C W$, v. I. London: International Publishers, 1975.

HOBSBWAM, E. et al. História do marxismo. Tradução de Carlos Nelson Coutinho e Nemésio Salles. Rio de Janeiro: Paz e Terra, 1983.

LÖWY, M. A teoria da revolução no jovem Marx. Tradução de Anderson Gonçalves. Petrópolis, RJ; Vozes, 2002. (Original publicado em 1938).

MARX, K. Cadernos preparatórios. In: . Diferença entre as filosofias da natureza em Demócrito e Epicuro. Tradução de Conceição Jardim e Eduardo Lúcio Nogueira. Lisboa: Presença, 1972a. (Original publicado em 1839). 
. Diferença entre as filosofias da natureza em Demócrito e Epicuro. 1972. Tese (Doutorado) - Tradução de Conceição Jardim e Eduardo Lúcio Nogueira. Lisboa: Presença, 1972b. (Original publicado em 1841).

. Anais franco-alemães (Deutsch-Französische Jahrbücher): introdução à crítica da filosofia do Direito de Hegel. In: BADIA, Gilbert; BANGE, P.; BOTTIGELLI, Emile. (org.). Sobre a religiāo. Tradução de Raquel Silva. Lisboa: Ediçôes 70, 1972c. (Original publicado em 1844).

. Reflections of a young man on the choice of a profession. Trier, Aug. In: MECW. London: International Publishers, 1975a. (Original publicado em 1835). V. 1.

. Letter to his father in Trier. In: MECW. London: International Publishers, 1975b. (Original publicado em 1837). V. 1.

. Comments on The Latest Prussian Censorship Instruction. Cologne, Febr. In: $M E C W$. London: International Publishers, 1975c. (Original publicado em 1842). V. 1.

. Letter to Arnold Ruge. Trier, March 5. In: MECW. London: International Publishers, 1975d. (Original publicado em 1842). V. 1.

. The question of centralisation in itself and with regard to the Supplement to n. 137 of the Rheinische Zeitung. Berlin, May. In: $M E C W$. London: International Publishers, 1975e. (Original publicado em 1842). V. 1.

. The leading article in n. 179 of the Kölnische Zeitung. In: $M E C W$, v. I. London: International Publishers, 1975f. [Editorial do n. 179 da Gazeta de Colônia. In: Sobre a Religiāo. Tradução de Raquel Silva. Paris: Éditions Sociales, 1975f. (Original publicado em 1842).

Letter to Arnold Ruge. Trier, July. In: $M E C W$. London: International Publishers, 1975g. (Original publicado em 1842). V. 1.

. Letter to Dagobert Oppenheim. Bonn, Aug. 25. In: MECW. London:

International Publishers, 1975h. (Original publicado em 1842). V. 1.

. Communism and the Augsburg Allgemeine Zeitung. In: MECW. London: International Publishers, 1975i. (Original publicado em 1842). V. 1.

. Debates on the law on Thefts of Wood. In: $M E C W$. London: International Publishers, 1975j. (Original publicado em 1842). V. 1.

. Letter to Arnold Ruge. In: MECW. v. I. London: International Publishers, 19751. (Original publicado em 1842). V. 1.

. The Supplement to n. 335 and 336 of The Augsburg Allgemeine Zeitung on the Commissions of the Estates in Prussia. In: $M E C W$, v. I. London: International Publishers, 1975m. (Original publicado em 1842). V. 1

. The philosophical manifesto of the historical school of law. In: $M E C W$, v. 2,

1975n. (Original publicado em 1842). V. 1. 
Critique of Hegel's philosophy of right. March 1842-August 1843. In:

Crítica da filosofia do direito de Hegel. Tradução de Conceição Jardim e Eduardo Lúcio Nogueira. Lisboa: Presença, 1983. (Original publicado em 1843).

PROUDHON, P-J. Qu'est-ce que la propriété? Recherche sur le principe du Droit et du Gouvernment. 1975. (Original publicado em 1840). Disponível em: http://www. marxists.org/reference/subject/economics/proudhon/property/index.htm. Acesso em: 24 mar. 2014.

ROUSSEAU, J. J. O contrato social: princípios do direito político. 3. ed. Tradução de Antônio de Pádua Danesi. São Paulo: Martins Fontes, 2003.

Recebido: 17/09/2016

Aceito: 08/12/2017 
VIEIRA, J. L. 